Article

\title{
Performance Analysis of Photovoltaic Integrated Shading Devices (PVSDs) and Semi-Transparent Photovoltaic (STPV) Devices Retrofitted to a Prototype Office Building in a Hot Desert Climate
}

\author{
Abdelhakim Mesloub 1,*(1), Aritra Ghosh 2,3,4,*®], Mabrouk Touahmia ${ }^{1}$, \\ Ghazy Abdullah Albaqawy ${ }^{1}$, Emad Noaime ${ }^{1}$ and Badr M. Alsolami ${ }^{5}$ \\ 1 Department of Architectural Engineering, Ha'il University, Ha'il 2440, Saudi Arabia; \\ m.touahmia@uoh.edu.sa (M.T.); g.albaqawy@uoh.edu.sa (G.A.A.); e.noaime@uoh.edu.sa (E.N.) \\ 2 Environment and Sustainability Institute, University of Exeter, Penryn, Cornwall TR10 9FE, UK \\ 3 College of Engineering, Mathematics and Physical Sciences, Renewable Energy, University of Exeter, \\ Cornwall TR10 9FE, UK \\ 4 Renewable Energy, Stella Turk Building, University of Exeter, Penryn, Cornwall TR10 9FE, UK \\ 5 Islamic Architecture Department, College of Engineering and Islamic Architecture, Umm Al-Qura \\ University, Mekkah 21955, Saudi Arabia; bmsolami@uqu.edu.sa \\ * Correspondence: a.maslub@uoh.edu.sa (A.M.); a.ghosh@exeter.ac.uk (A.G.)
}

Received: 24 October 2020; Accepted: 1 December 2020; Published: 4 December 2020

\begin{abstract}
This paper presents the impact on energy performance and visual comfort of retrofitting photovoltaic integrated shading devices (PVSDs) to the façade of a prototype office building in a hot desert climate. EnergyPlus ${ }^{\mathrm{TM}}$ and the DIVA-for-Rhino@ plug-ins were used to perform numerical simulations and parametric analyses examining the energy performance and visual comfort of five configurations, namely: (1) inclined single panel PVSDs, (2) unfilled eggcrate PVSDs, (3) a louvre PVSD of ten slats tilted $30^{\circ}$ outward, (4) a louvre PVSD of five slats tilted $30^{\circ}$ outward, and (5) an STPV module with $20 \%$ transparency which were then compared to a reference office building (ROB) model. The field measurements of an off-grid system at various tilt angles provided an optimum tilt angle of $30^{\circ}$. A $30^{\circ}$ tilt was then integrated into some of the PVSD designs. The results revealed that the integration of PVSDs significantly improved overall energy performance and reduced glare. The unfilled eggcrate PVSD did not only have the highest conversion efficiency at $n_{0} 20 \%$ but generated extra energy as well; an essential feature in the hot desert climate of Saudi Arabia.
\end{abstract}

Keywords: photovoltaic shading device (PVSD); overall energy; tilt angle; visual comfort; energy saving; hot desert climate

\section{Introduction}

Rapid population growth coupled with leaps in urbanisation and industrialisation over the last two decades have exponentially increased electricity demand in the Kingdom of Saudi Arabia [1-3]. In the north-western province of Ha'il, domestic energy consumption has skyrocketed to unprecedented levels, leading to increasingly frequent power outages during the harsh summer months, and sometimes during the unusually cold winters as well, when power demands peak. At present, the Kingdom is in the midst of implementing its ambitious Saudi Vision 2030 programme; an undertaking that seeks to drive economic development by building a thriving, diversified, and sustainable economy $[4,5]$. However, satisfying increasing domestic and industrial electricity demands while keeping greenhouse gas emissions low is a major challenge. As the present Saudi administration recognises the need 
to reduce the environmental impact of non-renewable energy sources, more consideration has been given to exploring alternative and more sustainable energy sources to improve the energy efficiency of buildings. Taking into account Saudi Arabia's abundance of solar radiance as well as its desert climate, photovoltaic (PV) technology could play a vital role in overcoming the energy issues of this hot and arid country [6]. As solar energy is easily converted into heat and electricity, it could power a significant proportion of domestic heating, ventilation, and air-conditioning (HVAC) systems, hot-water systems, lighting, and other key utilities.

The appeal of building-integrated photovoltaic (BIPV) systems is their ability to generate sustainable electricity simply by retrofitting building envelopes while simultaneously improving visual comfort [7-9]. Available in a variety of shapes, sizes, and designs, photovoltaic systems (PVs) blend seamlessly with commonly-used opaque and semi-transparent materials in architecture such as glass or metal, making them easy to integrate into every part of a building's envelope [9]. As such, PV systems such as photovoltaic integrated shading devices (PVSDs) are usually incorporated into building facades. A common trend in BIPV systems is the integration of different PVSD configurations into a facade, which serves as a new external skin for new and old buildings alike $[10,11]$. PVSD types include inclined single panel [12,13], outward tilted horizontal louvres [14,15], and unfilled eggcrate [16], as well as STPV modules [17] which are made of either crystalline silicon [18] thin-film PV [19], perovskite [20,21], or DSSC [22,23]. It is one of the more aesthetically pleasing architectural methods of converting excessive solar energy to electricity $[24,25]$.

A properly-designed PVSD system is capable of effectively saving energy, improving thermal comfort, and reducing the glare of buildings [26,27]. Wienold et al. [28] found that internal fixed shading devices had lower performance than their external counterparts and were less economical than dynamic systems. As the angle of inclination is an important parameter in evaluating PVSD performance, Zhang et al. [29] utilised a numerical simulation model to study the benefits and energy saving capabilities of PVSDs fixed at numerous tilt angles and orientations in Hong Kong. They discovered that a southern orientation and a $20^{\circ}$ tilt produced more overall energy benefits annually than interior blinds. An investigation of the thermal performance of PVSDs in winter by Yoo and Manz [30] found that they could be used as a double-envelope and insulation. Using DIVA Grasshopper 3D@ and the window-to-wall ratio (WWR) variable, Settino et al. [28] developed an evolutionary algorithm to optimise the size and shape of shading systems in three European cities. It found that an optimally designed PVSD system could reduce annual energy consumption by up to $42 \%$. Jayathissa et al. [31] examined the use of a dynamic integrated PV shading system to simultaneously optimise a building's energy demand and its PV energy output. Using a scale model and simulations to evaluate the performance and effect of louvre-integrated PV devices on indoor daylighting, Kim et al. [32] discovered that tilting the slats of a horizontal louvre to the downward position increased energy output and decreased indoor daylight levels. Sung et al. [33] developed louvre-integrated PV shading to enhance energy production and indoor visual comfort. Bellia et al. [34] investigated the influence of an external shading system on the energy consumption, space cooling, heating, and lighting of an ordinary Italian office. Khoroshiltseva et al. [35] used multi-objective optimisation analysis to design a versatile and efficient shading system that addressed increased energy demands in the winter for heating and lighting as well as cooling in the summer.

At present, because of the higher building energy consumption [36,37], powering buildings from $\mathrm{PV}$ is gaining importance. Imam et al. [38] investigated a grid-connected PV for building and from techno economic analysis it was found that $12.25 \mathrm{~kW}$ is the minimum requirement for a typical Saudi apartment. Lopez-Ruiz et al. [39] studied the potential of building roof top solar systems for Saudi Arabian architecture, which rarely employs the use of PVSDs. Only a few studies have investigated the overall energy performance of external fixed PVSDs over conventional shading devices [40] or examined the vertical and horizontal photovoltaic shading device in terms of insolation [4]. Therefore, this study performed a case study of the overall energy performance and visual comfort of five different configurations on a case study reference office building (ROB); the College of Engineering 
building of the University of Ha'il, which is located in a hot desert. The EnergyPlus ${ }^{\mathrm{TM}}$ programme [41] and the DIVA-for-Rhino@ software plug-in $[11,42]$ were used to model the ROB's HVAC system, daylighting, and solar gains as well as the energy produced as a consequence of PVSD integration. The maximum energy output of solar PVs tilted at various angles and degrees was analysed through experimental investigation with an off-grid system. Finally, the energy saving potential of prototype small offices retrofitted with each of the five configurations was analysed and compared to that of the ROB, an average Saudi Arabian office building.

\section{Methodology}

Numerical parametric simulations were used as a data collection tool to perform quantitative and qualitative analyses. The following sections present the research materials and methods implemented in the study.

\subsection{Case Study (ROB) and Climate}

The prototype small office model (Figure 1c) was a curtain wall design with a fixed window-to-wall ratio (WWR) of 30\%. The model featured two windows recessed at a depth of $30 \mathrm{~cm}$ and fitted with argon gas-filled double-glazed window panes coated with low emissive (low-E) glass that has a visible light transmittance (VLT) of 0.79 . SketchU $\mathrm{p}^{\mathrm{TM}}$ was used to design the prototype small office model before it was exported to EnergyPlus ${ }^{\mathrm{TM}}$ to assess the energy saving potential of each configuration. This data was then compared to a case study reference office building (ROB), the College of Engineering building at the University of Ha'il. Built on flat ground with no shading from adjacent buildings, the $\mathrm{ROB}$ is $2.80 \times 4.60 \mathrm{~m}$ and $3.0 \mathrm{~m}$ in height, lateral in typology, and has south-facing office units on the second floor that are separated by a central corridor.

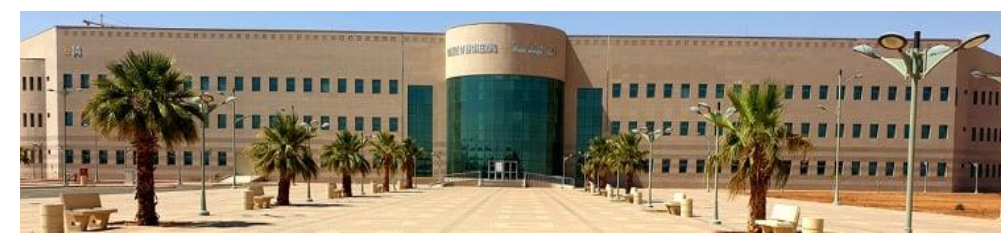

(a)

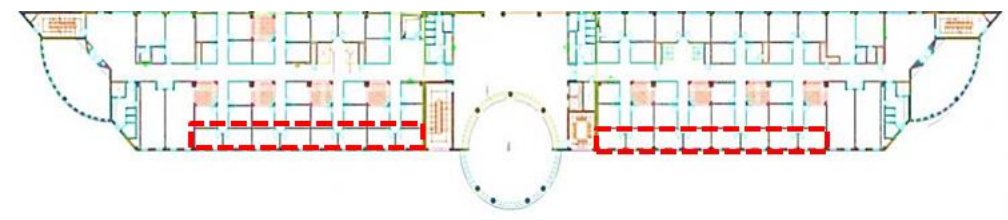

(b)

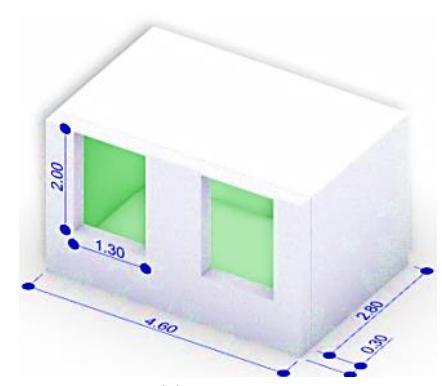

(c)

Figure 1. (a) The southern façade of the case study reference office building (ROB), the College of Engineering at the University of $\mathrm{Ha}^{\prime} \mathrm{il}(\mathrm{UoH})$; (b) the location of the tested offices in the ROB; and (c) a prototype model of a small office. 
Situated at $27^{\circ} 31^{\prime} \mathrm{N}$ latitude and $41^{\circ} 41^{\prime} \mathrm{E}$ longitude, according to the Köppen climate classification, the location of our chosen ROB is a dry desert with a mean temperature of $31.1^{\circ} \mathrm{C}$ in August (warmest month) and $10.6{ }^{\circ} \mathrm{C}$ in January (coolest month) while the average annual temperature is $20.9{ }^{\circ} \mathrm{C}$ (Figure 2). Its location also provides lots of solar radiance and daylight throughout the year for free. Therefore, it is preferable to utilise maximum daylighting in the building during the daylight hours. As such, a fully clear sky was selected as the standard design in the prototypes.

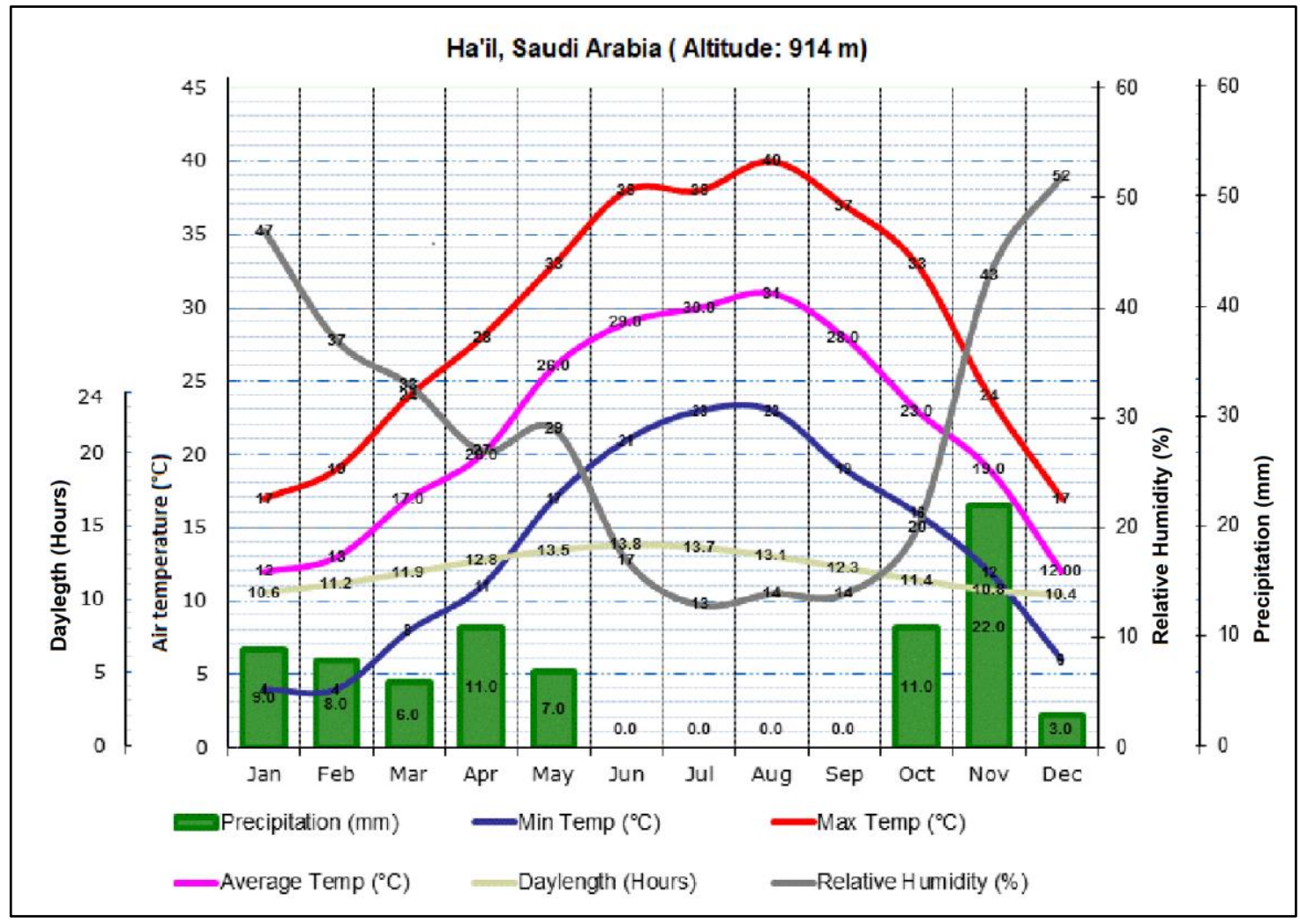

Figure 2. Monthly climatic data of Ha'il city.

\subsection{PVSD Configurations}

This study mainly focused on the overall energy performance of prototype small offices retrofitted with each of the five configurations (Table 1). As the angles, dimensions, and design of these configurations needed to be able to be retrofitted to building fenestrations to achieve maximum energy savings, uniformity of daylighting to reduce artificial lighting energy consumption, and maximum energy production for cooling and heating when required, the following five configurations were examined:

1. An inclined single panel PVSD.

2. An unfilled eggcrate PVSD.

3. A louvre of ten outward-tilted slats.

4. A louvre of five outward-tilted slats.

5. A semi-transparent photovoltaic (STPV) module with $20 \%$ transparency. 
Table 1. The different PVSDs configurations used in the simulations.

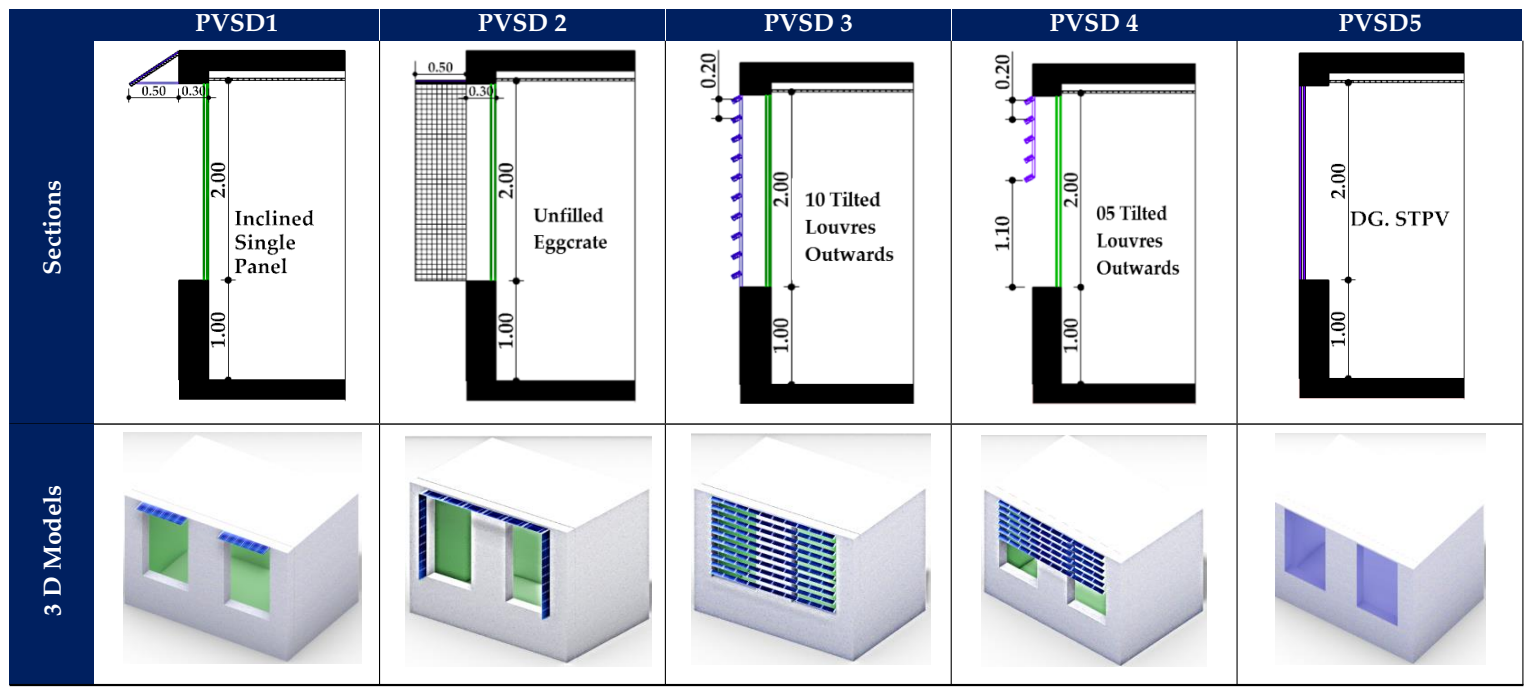

The curtain wall 3D model of each configuration featured two $30 \mathrm{~cm}$-recessed windows. The inclined single panel configuration (PVSD1) was designed to overhang the tops of both windows by $50 \mathrm{~cm}$ without spacing and to tilt downward by $30^{\circ}$ to avoid direct sunlight during excessively hot periods. In the unfilled eggcrate configuration (PVSD2), one horizontal $50 \mathrm{~cm}$-photovoltaic panel skirted the top of both windows while two vertical $50 \mathrm{~cm}$-photovoltaic panels bordered the left and right sides. In PVSD3, a louvre of ten $10 \mathrm{~cm}$-slats was tilted downward at a $30^{\circ}$ angle and spaced $20 \mathrm{~cm}$ apart to avoid mutual shading throughout the day. This layout was duplicated in PVSD4 with only five slats across the top half of both windows to improve the users' field of vision. Finally, PVSD5 placed a semi-transparent photovoltaic (STPV) module, with 20\% transparency, at the outer edge of both windows to prevent shaded areas in the PV panel. These PVSDs were not connected to grid thus no grid inverters were employed for study. Additionally, because of the nature of the PVSD, no inverters were considered in this study. Prime focuses were to find the building energy saving through exploiting daylighting, controlling solar heat gain, and generating DC power.

\subsection{PV Energy Output Simulations}

The meteorological data of the city of Ha'il was extracted from the Meteonorm $\subset$ database and used in the EnergyPlus ${ }^{\mathrm{TM}}$ simulations. EnergyPlus ${ }^{\mathrm{TM}}$ "Equivalent One-Diode model"; which uses an empirical relationship to predict the operating performance of the PV based on conditions such as the temperature of the PV cell, and estimate the conversion efficiency of each time-step empirically (that cannot be determined directly through physical measurements), was then used to estimate the irradiation of tilted surfaces. The simulation programme used data from the manufacturer's catalogue (Table 2) to calculate these values.

Table 2. Electrical characteristics under standard test conditions (STC) of different PV types.

\begin{tabular}{ccc}
\hline & Electrical Properties (STC) & \\
\hline Array Types & PVSD Multi-Crystalline & STPV Thin-Film (Amorphous) \\
\hline Dimension (length, width, thickness) & $767 \times 502 \mathrm{~mm}$ & $2000 \times 1300 \mathrm{~mm}$ \\
Max power (Pmax) & $40 \mathrm{watt}$ & $88.4 \mathrm{watt}$ \\
Efficiency of module (n) & $10 \%$ & $3.4 \%$ \\
Max power voltage (Vpm) & $21 \mathrm{~V}$ & $78 \mathrm{~V}$ \\
Max power current (Ipm) & $2.37 \mathrm{~A}$ & $1.15 \mathrm{~A}$ \\
Open circuit voltage & $21 \mathrm{~V}$ & $100 \mathrm{~V}$ \\
Short circuit current & $2.58 \mathrm{~A}$ & $1.43 \mathrm{~A}$ \\
\hline
\end{tabular}




\subsection{Experiment Validation of PV Energy Output}

At present, energy model simulation tools are used with greater frequency to measure energy output. Although most of these simulation tools employ standard sky types, as defined by the Commission Internationale de l'Éclairage (CIE), their accuracy and applicability in the Saudi Arabian climate warrants validation.

As such, the energy output of an off-grid system was measured. The system was set up according to the $\operatorname{VDAS}^{\circledR}$ (Versatile Data Acquisition System); a standard arrangement of a multi-crystalline photovoltaic panel array, battery storage, and a solar charge controller (Figure 3). Measurements were taken under clear skies in spring, between 15 and 18 March 2020. These measured values were then compared to the values derived using EnergyPlus ${ }^{\mathrm{TM}}$ to validate PV energy outputs. The American Society of Heating, Refrigerating and Air-Conditioning Engineers (ASHRAE)eveloped Guideline 14 strongly recommends that the mean bias error (MBE) should be less than $10 \%$ while the coefficient of variation of the root mean square error (CV(RMSE)) should be less than $30 \%$ in order to validate a PVSD energy model [43].

$$
\begin{gathered}
\operatorname{MBE}(\%)=\frac{\sum_{\mathrm{i}=1}^{\mathrm{Np}}(\mathrm{mi}-\mathrm{si})}{\sum_{\mathrm{i}=1}^{\mathrm{Np}}(\mathrm{mi})} \\
\text { CV RMSE }=\frac{\sqrt{\sum_{\mathrm{i}=1}^{\mathrm{Np}}(\mathrm{mi}-\mathrm{si})^{2}} / \mathrm{Np}}{\mathrm{m}}
\end{gathered}
$$

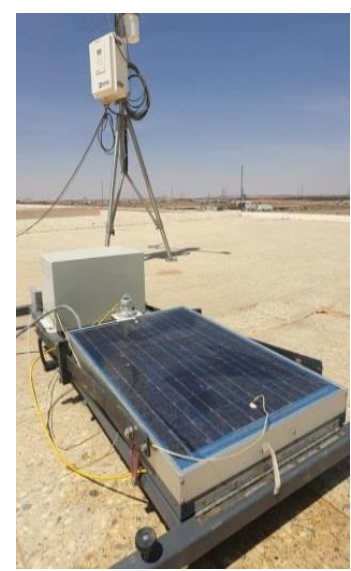

(a)

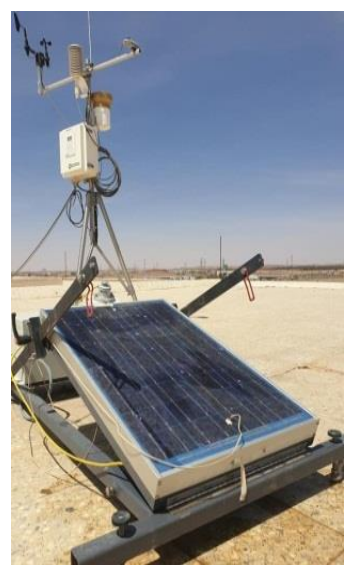

(b)

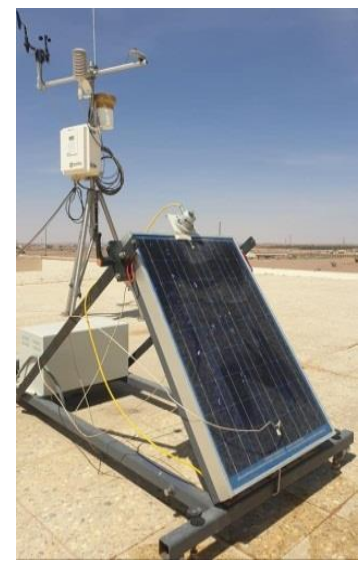

(c)

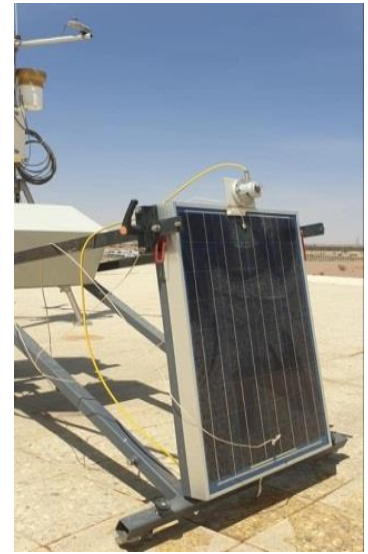

(d)

Figure 3. Field measurements of an off-grid PV system with different tilt angles: (a) horizontal angle; (b) tilted with $30^{\circ}$; (c) tilted with $60^{\circ}$; (d) tilted with $90^{\circ}$.

\subsection{Thermal Simulation}

Dynamic thermal simulations were performed using the Ideal Loads Air Systems (ILAS); an ideal HVAC system with a coefficient of performance (COP) of one. To satisfy the accepted operative temperature of a new office building as well as the required zone temperature set-point as per ISO 7730, the ILAS HVAC was assumed to supply sufficient cooling and heating at $20^{\circ} \mathrm{C}$ and $26^{\circ} \mathrm{C}$ air temperature, respectively [44]. As the regulation policy of Saudi Arabia stipulates that heating and cooling systems are only to be turned on during working hours, the occupancy schedule of the office building was set to between 08:00 and 17:00 from Sunday to Thursday and considered closed on weekends and bank holidays. The construction materials of the office building, as well as their thermo-physical properties, were exported to OpenStudio ${ }^{\circledR}$ for building energy analysis. Table 3 shows extracts of optical properties as taken from WINDOW 7.7, a windows and daylighting software. 
Table 3. Thermal properties of external wall building and glazing layers.

\begin{tabular}{|c|c|c|c|}
\hline Material (External Wall Layers) & $\mathrm{k}(\mathrm{W} / \mathrm{m} \cdot \mathrm{K})$ & $\rho\left(\mathrm{kg} / \mathrm{m}^{3}\right)$ & c (J/kg.K) \\
\hline H.W.H.C.B. $(150 \mathrm{~mm})$ & 0.96 & 1362 & 879 \\
\hline Thermal insulation ( $30 \mathrm{~mm}$ ) & 0.04 & 91 & 837 \\
\hline H.W.H.C.B. $(100 \mathrm{~mm})$ & 0.81 & 1618 & 879 \\
\hline Gypsum board (19 mm) & 0.16 & 785 & 1090 \\
\hline Glazing (Optical and Thermal properties) & VLT & U-value & SHGC \\
\hline Double glazing low-E - Argon gas & 0.79 & 1.10 & 0.65 \\
\hline Double glazing semi-transparent PV & 0.20 & 2.70 & 0.14 \\
\hline
\end{tabular}

\subsection{Daylighting and Lighting Energy Simulations}

In the artificial lighting simulations, a photosensor was used to dim the activated lighting until the work plane illuminance reached the desired value of $300 \mathrm{~lx}$. However, artificial lighting was assumed to be switched on during the occupancy hours of 08:00 to 17:00. Their operating profiles follow their real use. To evaluate indoor visual comfort, the DIVA-for-Rhino@ plug-in was used to obtain daylight autonomy (DA) and useful daylight illuminance (UDI) metrics [45]. The UDI bin was set to 100 to 2000 lx while the DA threshold was set to 300 lx. Glare analyses were also performed by calculating the daylight glare probability (DGP) and the 3D illuminance contour map of each configuration. The international standard (Table 4) was selected as the performance indicator.

Table 4. The performance indicators of visual comfort used in this study.

\begin{tabular}{ccc}
\hline Analysis & Criteria & Performance Indicator \\
\hline & UDI & 100 lux $<$ Dark area (need artificial light) \\
& DA & 100 lux -2000 lux (comfortable), at least $50 \%$ of the time \\
Quantitative + qualitative & WPI & Set up 300 lx \\
& & WPI recommended $300-500$ lux \\
& DGP & $0.35<$ imperceptible glare \\
& & $0.35-0.40$ perceptible glare \\
& $0.4-0.45$ disturbing glare \\
& $>0.45$ intolerable glare \\
\hline
\end{tabular}

\section{Results and Discussion}

\subsection{Analysis and Validation of Energy Outputs at Different Tilt Angles}

For greater accuracy, the energy output of the off-grid system and EnergyPlus ${ }^{\mathrm{TM}}$ data at different tilt angles $-0^{\circ}$ (horizontal), $30^{\circ}, 60^{\circ}$, and $90^{\circ}$ (vertical)—were measured hourly over four different days and compared (Figure 4). The energy output of the EnergyPlus ${ }^{\mathrm{TM}}$ simulations was slightly higher for all tilt angles than the off-grid system results, particularly at midday. A maximum energy output of $38 \mathrm{~W} / \mathrm{h}$ was observed at $1.00 \mathrm{p} . \mathrm{m}$. when the panel was titled at $30^{\circ}$. This proved the validity and reliability of the EnergyPlus ${ }^{\mathrm{TM}}$ simulations as the MBE of the $0^{\circ}, 30^{\circ}, 60^{\circ}$, and $90^{\circ}$ tilted models were between $5.4 \%, 6 \%, 9.2 \%$, and $11 \%$, respectively, while the CV(RMSE) of the $0^{\circ}$ tilted model was $7.28 \%$ and $12.45 \%$ for the $90^{\circ}$ tilted model.

Figure 5 presents the hourly energy output of the angles over four different seasons. As the PV energy output at $0^{\circ}$ tilt was generally higher than the $90^{\circ}$ tilt, therefore, it could be used as a PVSD. The $30^{\circ}$-tilt PV produced the highest amount of electricity daily in all seasons except summer while the $0^{\circ}$-tilt PV produce more electricity overall as it had a southern orientation and due to the sun path position, therefore, received more solar radiance. It is remarkable that the value of indoor illuminance (lux) reduced in the evening period of 21 of June because of reduction of external illuminance, where the sky condition changed from clear sky to an overcast sky. The annual energy output of the $30^{\circ}$-tilt $\mathrm{PV}$ was up to $91.7 \mathrm{kWh} /$ year (Appendix A). It is also noteworthy that the daily energy output of the $90^{\circ}$-tilt PV was only $12 \%$ to $43 \%$ compared to the $30^{\circ}$-tilt PV in all seasons. As such, a $30^{\circ}$ tilt was integrated into the design of the inclined single panel, tilted 10-slat louvre, and tilted 5-slat louvre PVSDs. 

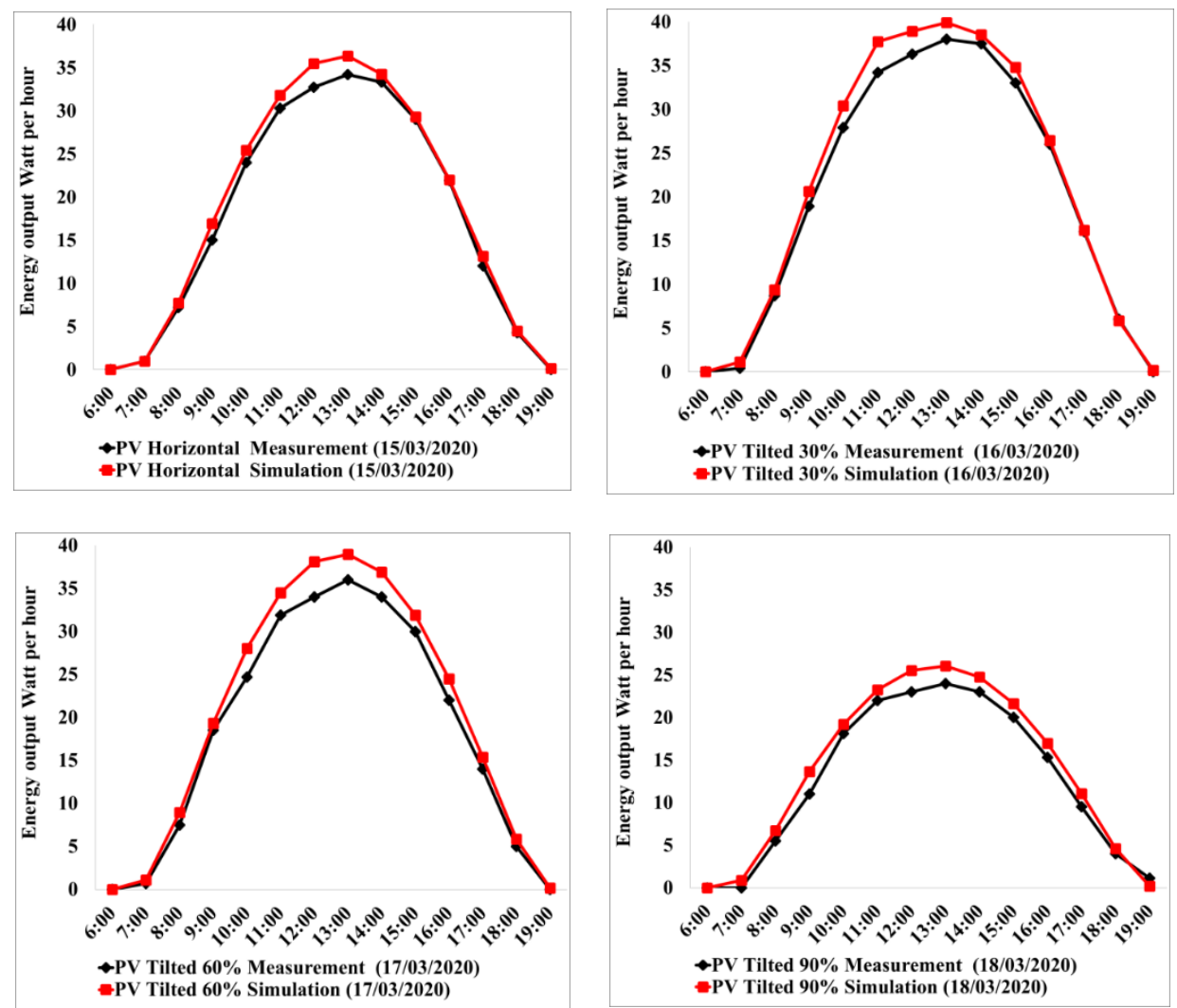

Figure 4. Validation of the energy output of the $0^{\circ}, 30^{\circ}, 60^{\circ}$, and $90^{\circ}$ tilted models over four days in spring.

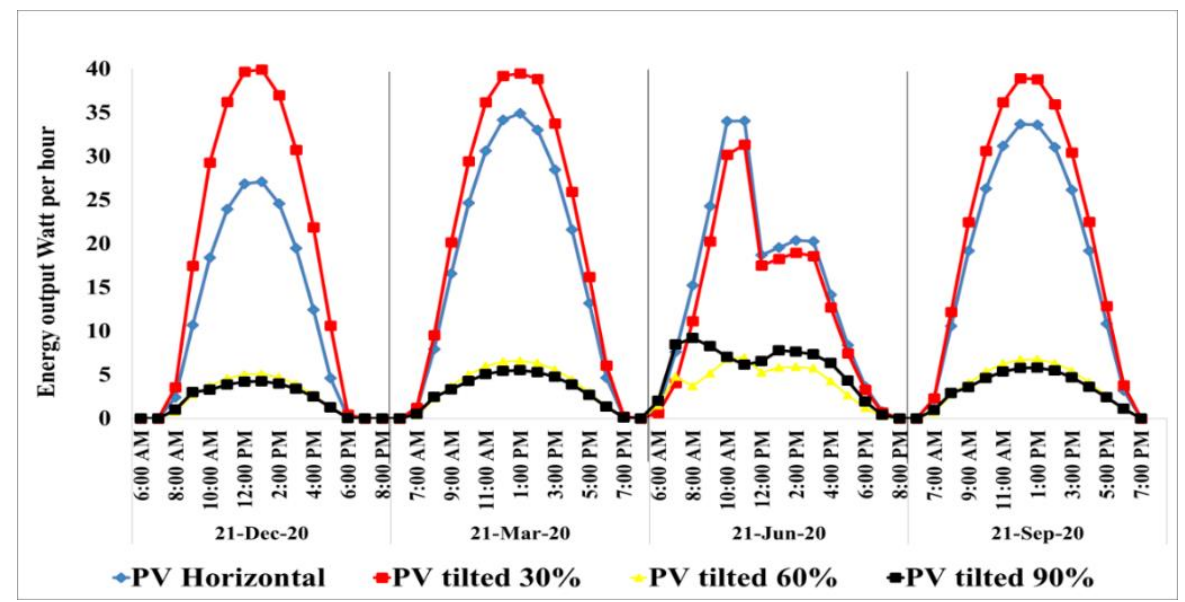

Figure 5. The hourly energy output of the different tilt angles across four seasons.

\subsection{Energy Performance}

EnergyPlus ${ }^{\mathrm{TM}}$ used Ha'il city's hourly weather data from the Meteonorm (C) database to simulate the annual energy performance of the different PVSDs. Figure 6 presents the cooling and heating loads, artificial lighting, energy consumption, as well as the energy generated by the ROB, PVSDs, and the STPV module. 


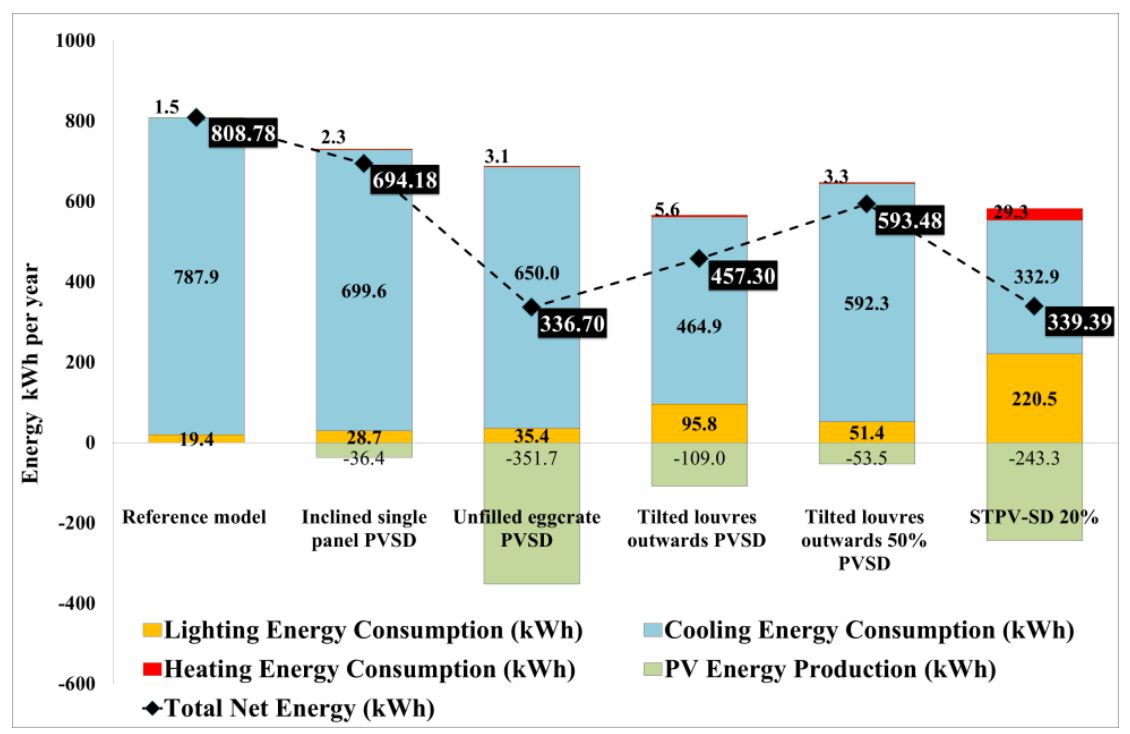

Figure 6. Yearly overall energy performance of the different configurations.

The simulation results indicated that the $\mathrm{ROB}$ and the configurations expended the most energy on cooling annually. The ROB utilised $97.5 \%$ of its total net energy on cooling while the inclined single panel, unfilled eggcrate, tilted 10-slat louvre, and tilted 5-slat louvre PVSDs consumed only $2 \%, 4 \%, 21 \%$, and $9.24 \%$ less energy on cooling, respectively. However, the solar heat gain coefficient (SHGC) and heat energy transferred through a window (U-value) (Table 2) of the double-low-E glass used in the STPV modules reduced its cooling energy consumption by up to $75 \%$. In contrast, the heating energy consumption per annum was negligible and, at the most, did not exceed $6 \%$ in the STPV module due to a lack of solar transmission.

PVSDs were found to increase the annual lighting energy consumption by up to $21 \%$ compared to the ROB while the STPV module recorded the highest energy consumption ( $220.5 \mathrm{kWh})$ due to its low VLT rate, only $20 \%$. This finding was corroborated by one other study [46].

The unfilled eggcrate PVSD had the highest amount of annual PV energy production ( $351.7 \mathrm{kWh}$ ) followed by the STPV module $(243.3 \mathrm{kWh})$ as they received more solar radiance than the other PVSDs in winter. The energy output of both these configurations was able to satisfy approximately $50 \%$ of their respective energy demands. As the single inclined panel, tilted 10-slat, and 5-slat louvre PVSDs produced the least amount of energy, therefore, the addition of a $30^{\circ}$ tilt to the panels did not generate more energy as it reduced the surface area exposed to solar radiance. The efficiency of the unfilled eggcrate, single inclined panel, tilted 10-slat, and 5-slat louvre PVSDs was approximately 10\% each and $3.4 \%$ for the STPV module (Table 2).

The overall energy consumption (OEC) trend of the ROB indicated that the use of recessed windows in hot desert climates was counterproductive as it enabled more heat transfer (U) into the ROB. In contrast, the addition of these configurations (PVSDs) not only significantly reduced cooling energy consumption but produced a considerable amount of electricity as well. Although they increased heating and lighting energy consumption, this was negligible compared to their reduction in cooling loads. Therefore, a balanced and carefully selected optimum configuration should be applied to all buildings.

\subsection{Daylighting and Visual Comfort}

Figure 7 presents the mean daylight autonomy (DA) and useful daylight illuminance (UDI) metrics within the ROB and the prototype small office models of the configurations. The ROB had the highest mean DA300 lx and UDI 100 to 2000 lx percentages with only moderate visual discomfort. The 20\% transparency of the STPV module did not meet the minimum requirements of the mean DA and 
recorded $0 \%$ while its UDI $<100$ lx exceeded $90 \%$ thereby requiring the use of artificial light throughout the occupancy hours. Only the inclined single panel PVSD exceeded the 50\% threshold of the DA300 lx while all the configurations achieved the mean UDI of 100 to 2000 lx. Only the tilted 10-slat louvre PVSD and the STPV module were able to totally eliminate visual discomfort (UDI < 2000).

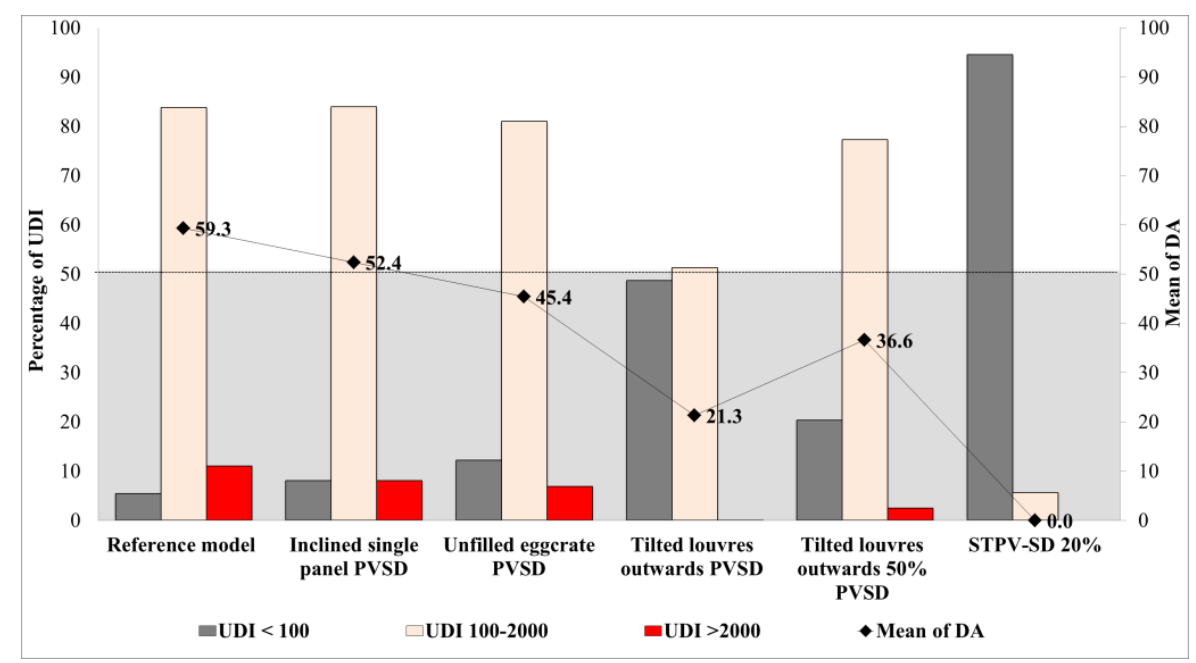

Figure 7. Climate-based analysis of annual mean daylight autonomy (DA) and useful daylight illuminance (UDI) of the ROB and the configurations.

\subsection{Daylight Glare Probability}

Table 5 shows the glare discomfort caused by the ROB and the configurations. Daylight glare probability (DGP), 3D illuminance contour map metrics, and mean illuminance were used to assess the glare of each configuration. As seen in Figure 8, the ROB had the lowest mean DGP; the perceptible and disturbing glare mainly appeared in winter season between $10 \mathrm{a} . \mathrm{m}$. and $3 \mathrm{p} . \mathrm{m}$. and the DGP value was between 27 and 40 over the four assessment days (refer to Appendix B for more details). The mean DGPs were within acceptable limits during the summer solstice and spring equinox but, during the winter solstice, disturbing glare was detected at 12:00 and perceptible glare at 09:00 and 15:00. The integration of a $30^{\circ}$ tilt to the 10-slat and 5-slat louvre PVSDs decreased the contour shape during the winter solstice and produced an imperceptible glare with a mean illuminance ranging between 367 and 516 lx. The inclined panel PVSD had the least glare with a mean illuminance of between 765 and $2123 \mathrm{~lx}$, which is higher than the recommended value. Overall, the configurations considerably enhanced visual comfort with a minimum $2^{\circ}$ reduction in mean DGP compared to the ROB. Hence we can claim that PVSDs are suitable for winter season while STPVs with 20\% of transparency totally eliminate the glare issue but do not provide sufficient indoor illuminance.

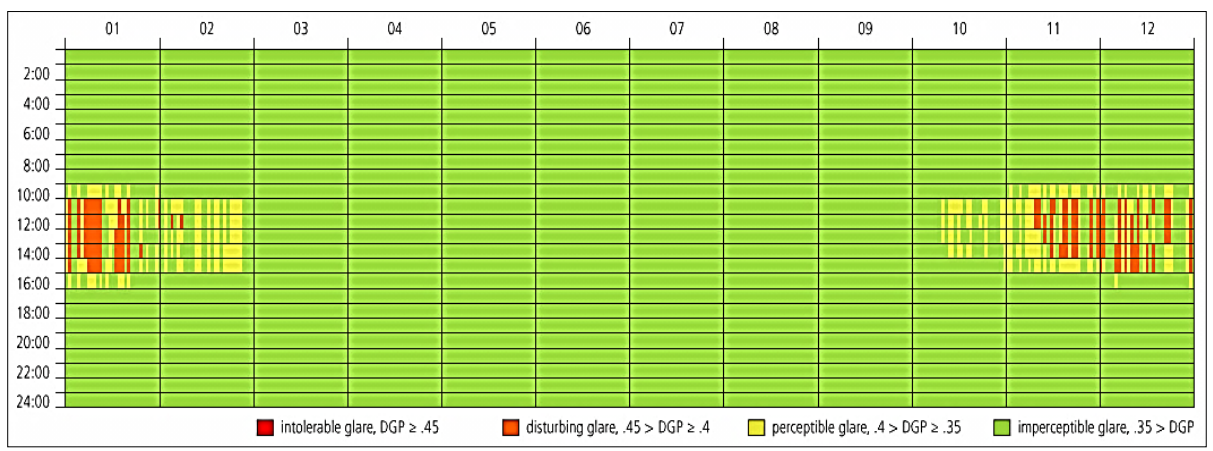

Figure 8. Annual daylight glare probability (DGP) analysis of ROB. 
Table 5. The illuminance contour map of PVSDs configurations under clear sky at summer and winter solstice and spring equinox at (9.00 a.m., 12.00 p.m., 3.00 pm).

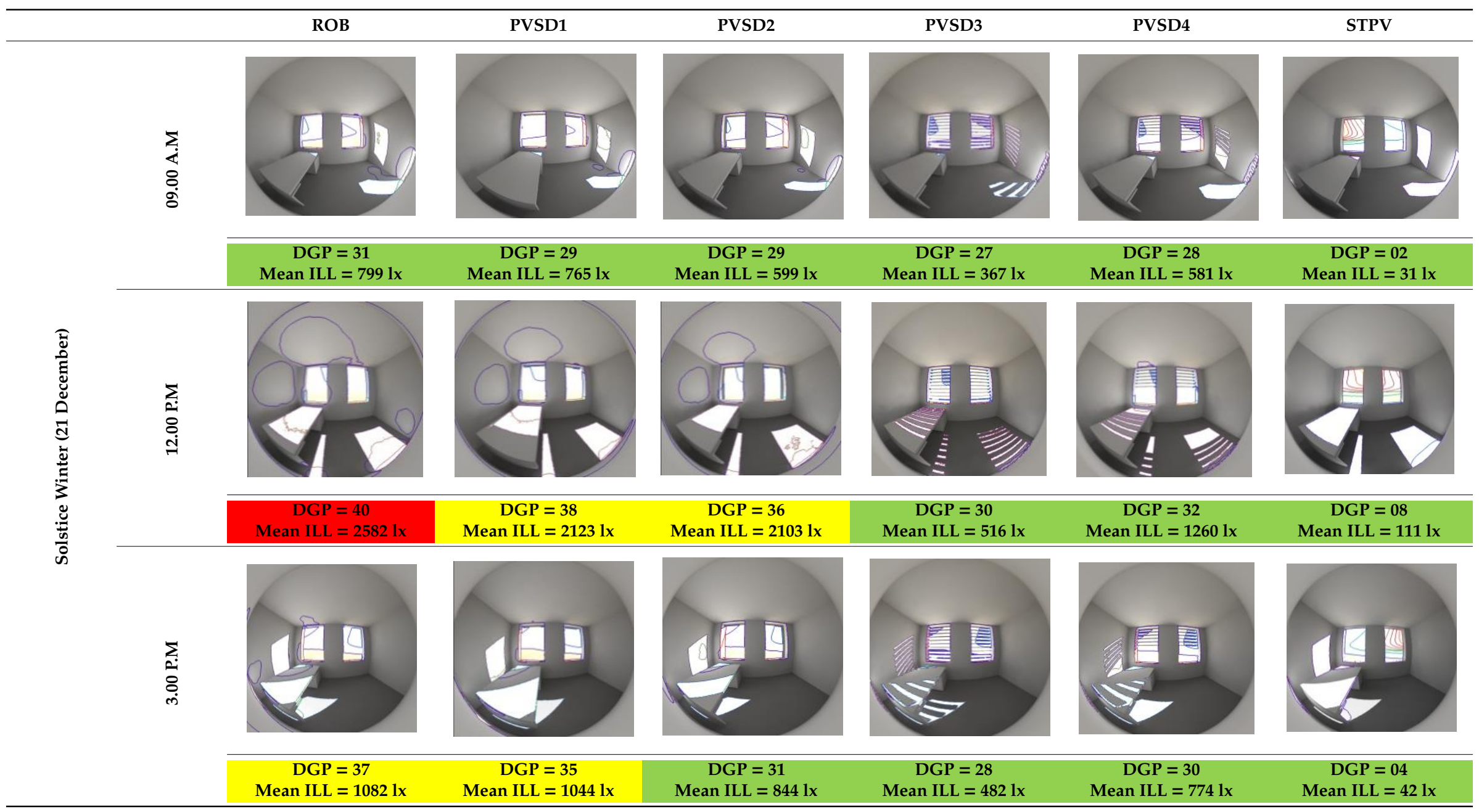


Table 5. Cont.

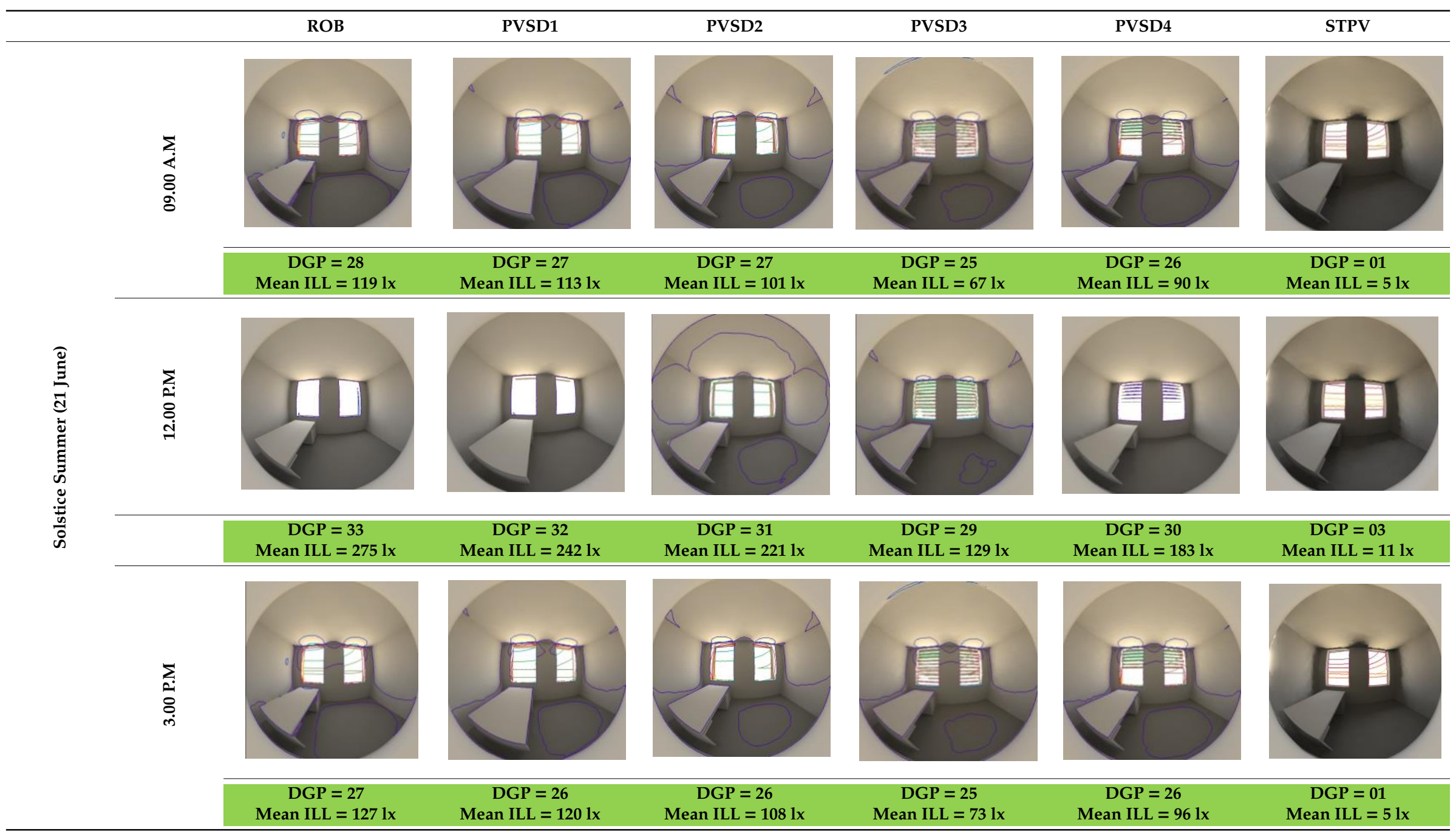


Table 5. Cont

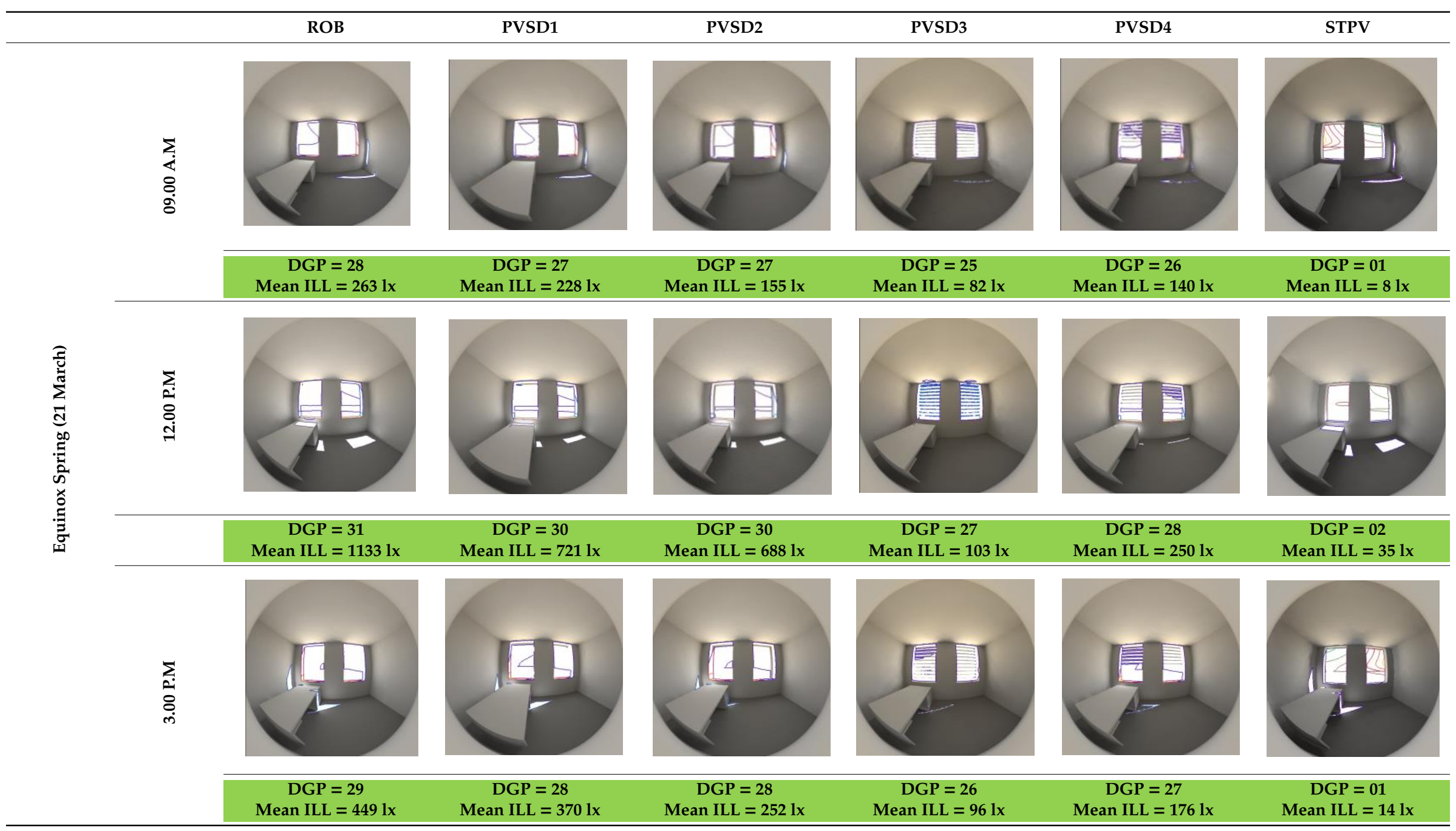




\subsection{Energy Saving Potential}

Figure 9 presents the energy saving potential of the PVSDs at varying efficiencies $(n, 10 \%, n 15 \%$ and $\mathrm{n}, 20 \%$ ) and the STPV module at $\mathrm{n}, 3.1 \%$. Although all the configurations had energy savings ranging between approximately $14.2 \%$ to plus-energy, the results were positive across the board in comparison to the ROB. The unfilled eggcrate PVSD saved the most energy, $58.4 \%$ to $101.9 \%$, at conversion efficiencies of between $n, 10 \%$ to $n 20 \%$, respectively, as the horizontal and vertical configuration of its $\mathrm{PV}$ panels enabled it to receive maximum solar radiance, thereby producing more energy in addition to reducing its cooling energy consumption. Although the STPV module saved energy by $58 \%$, it was at a very low conversion efficiency of $n 3.4 \%$. This proved that thermal performance was more important than conversion efficiency. This configuration also did not meet minimum visual comfort requirements due to the low transparency of STPV window technology. It was discovered that the tilted 10-slat louvre PVSD could provide nearly twice the amount of energy savings than the tilted 5 -slat louvre PVSD. However, the latter configuration omitted to install slats in the lower section of the window to provide users with a view of the outdoors. Finally, the inclined single panel PVSD had the worst energy saving potential of the five configurations. Therefore, a balanced trade-off between the thermal properties of glazing, the conversion efficiency of the PV panels, and visual comfort is vital to achieve a plus-energy building.

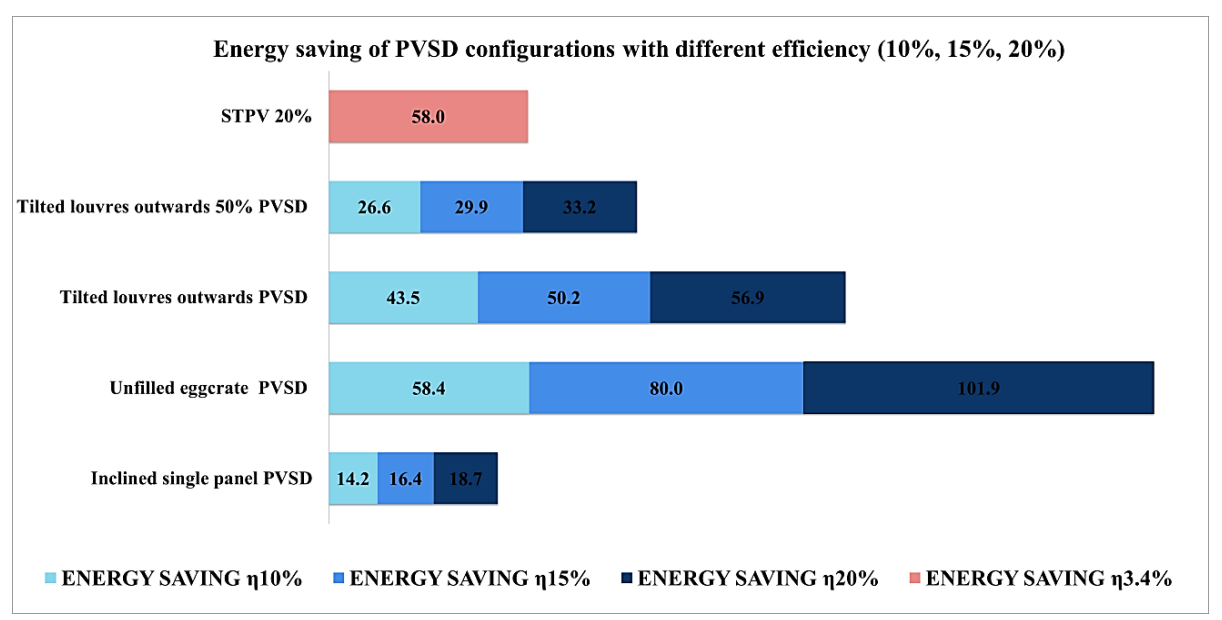

Figure 9. Energy saving percentages at different PV conversion efficiencies in comparison to the ROB.

\section{Conclusions}

This study examined for the first time the impact on overall energy performance and visual comfort of retrofitting four different PVSD configurations and one STPV module to a south-facing prototype small office model in the College of Engineering building of the University of Ha'il, under a hot desert climate, using Energy-plus and DIVA-for-Rhino@ plug in building energy simulation tools. A comprehensive analysis of the yearly and hourly energy output of various tilt angles was first performed using an off-grid system to determine the optimum tilt angle, $30^{\circ}$, as well as to validate the data of our simulation models. A $30^{\circ}$ tilt was integrated into the design of the inclined single panel, tilted ten-slat louvre, and tilted five-slat louvre PVSDs to attain maximum energy output. In order to select the optimum configuration, it is necessary to find a delicate balance between visual comfort and energy performance. The results of our simulations highlighted the following important points:

- Climate profoundly affected cooling and heating energy consumption as the integration of outward tilted slats in the louvre PVSDs as well as the double-low-E window pane of the STPV module significantly reduced cooling and heating energy consumption due to the thermal properties of the STPV window pane compared to double-low-E window panes applied in other configurations. Furthermore, it blocked direct solar radiance throughout the year. 
- Although an effective configuration and daylight control strategy could eliminate glare discomfort, they increased lighting energy consumption, particularly in the STPV module.

- The unfilled eggcrate PVSD was the optimum configuration as it could produce plus energy by means of conversion efficiency $n=20 \%$ while simultaneously providing visual comfort.

This study contributes to knowledge on PVSD and STPV module integration into office building envelopes in hot desert climates. Policymakers and architects may utilise the results of this research to retrofit PVSDs and STPV windows to conventional buildings in similar climates. However, future studies may focus on the return on investment (ROI) as well as other building typologies. In conclusion, the integration of PVSD systems and STPV modules into the building envelope offers large energy saving potential that could surpass zero net energy consumption, enhances visual comfort, and contributes to lower $\mathrm{CO}^{2}$ emissions.

Author Contributions: Conceptualization, A.M., M.T. and A.G.; methodology, A.M.; software, A.M.; validation, A.M.; formal analysis, A.M.; investigation, A.M.; resources, A.M.; data curation, A.M. and A.G.; writing-original draft preparation, A.M.; writing-review and editing, A.G., M.T., G.A.A., B.M.A.; visualization, A.G., E.N. and M.T. All authors have read and agreed to the published version of the manuscript.

Funding: This research has been funded from the Research Deanship at University of Ha'il - Saudi Arabia through project number RG- 20105.

Conflicts of Interest: The authors declare no conflict of interest.

Appendix A

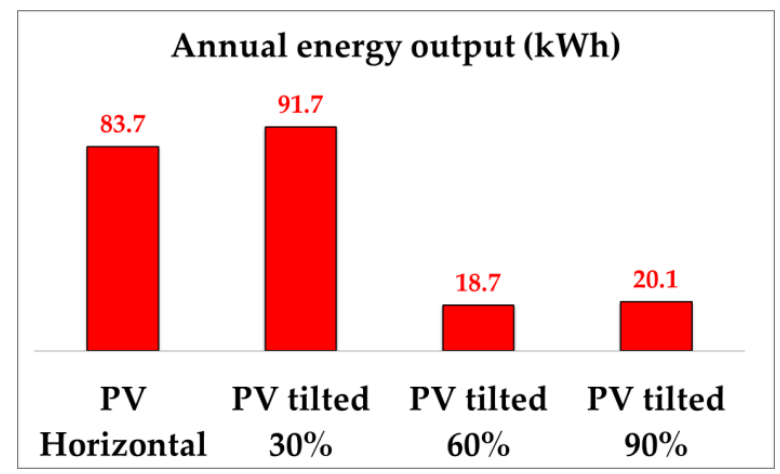

Figure A1. Annual energy output of different tilted angle of an off-grid PV system.

\section{Appendix B}
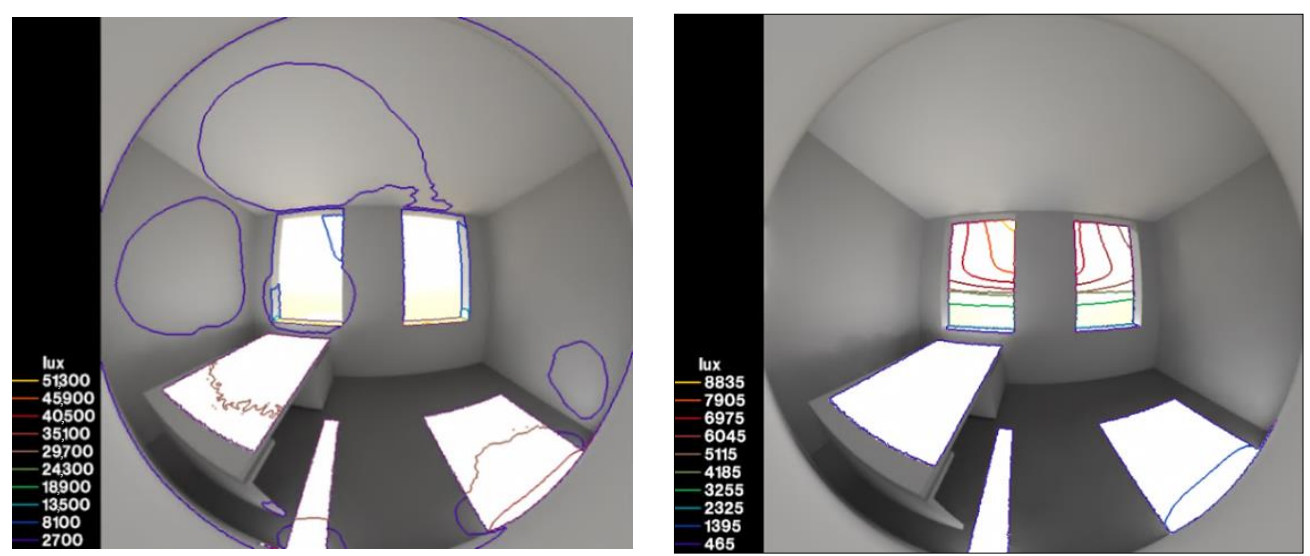

Figure A2. (The worst case) 3D illuminance contour map of the ROB compared with STPV configuration on winter solstice at midday. 


\section{References}

1. Almasoud, A.H.; Gandayh, H.M. Future of solar energy in Saudi Arabia. J. King Saud Univ. Eng. Sci. 2015, 27, 153-157. [CrossRef]

2. Alshahrani, J.; Boait, P. Reducing high energy demand associated with air-conditioning needs in Saudi Arabia. Energies 2019, 12, 87. [CrossRef]

3. Zubair, M.; Bilal Awan, A.; Al-Ahmadi, A.; Abo-Khalil, A.G. NPC based design optimization for a net zero office building in hot climates with PV panels as shading device. Energies 2018, 11, 1391. [CrossRef]

4. Asfour, O.S. Solar and shading potential of different configurations of building integrated photovoltaics used as shading devices considering hot climatic conditions. Sustainability 2018, 10, 4373. [CrossRef]

5. Saudi Vision 2030. Available online: https://vision2030.gov.sa/en/node/6 (accessed on 2 December 2020).

6. Zell, E.; Gasim, S.; Wilcox, S.; Katamoura, S.; Stoffel, T.; Shibli, H.; Engel-Cox, J.; Al Subie, M. Assessment of solar radiation resources in Saudi Arabia. Sol. Energy 2015, 119, 422-438. [CrossRef]

7. Abdelhakim, M.; Kandar, M.Z.; Lim, Y.-W. Experimental Investigation of Overall Energy Performance in Algerian Office Building Integrated Photovoltaic Window under Semi-Arid Climate. J. Daylighting 2019, 6, 23-41. [CrossRef]

8. Strong, S. Building integrated photovoltaics (BIPV). Whole Build. Des. Guide 2010, 9. Available online: https: //www.wbdg.org/resources/building-integrated-photovoltaics-bipv?r=env_preferable_products (accessed on 2 December 2020).

9. Skandalos, N.; Tywoniak, J. Influence of PV Facade Configuration on the Energy Demand and Visual Comfort in Office Buildings; Journal of Physics: Conference Series; IOP Publishing: Bristol, UK, 2019.

10. Zhang, X.; Lau, S.K.; Lau, S.S.; Zhao, Y. Photovoltaic integrated shading devices (PVSDs): A review. Sol. Energy 2018, 170, 947-968. [CrossRef]

11. Mohsenin, M.; Hu, J. Assessing daylight performance in atrium buildings by using Climate Based Daylight Modeling. Sol. Energy 2015, 119, 553-560. [CrossRef]

12. El Gindi, S.; Abdin, A.R.; Hassan, A. Building integrated photovoltaic retrofitting in office buildings. Energy Procedia 2017, 115, 239-252. [CrossRef]

13. Stamatakis, A.; Mandalaki, M.; Tsoutsos, T. Multi-criteria analysis for PV integrated in shading devices for Mediterranean region. Energy Build. 2016, 117, 128-137. [CrossRef]

14. Hofer, J.; Groenewolt, A.; Jayathissa, P.; Nagy, Z.; Schlueter, A. Parametric analysis and systems design of dynamic photovoltaic shading modules. Energy Sci. Eng. 2016, 4, 134-152. [CrossRef]

15. Taveres-Cachat, E.; Bøe, K.; Lobaccaro, G.; Goia, F.; Grynning, S. Balancing competing parameters in search of optimal configurations for a fix louvre blade system with integrated, P.V. Energy Procedia 2017, 122, 607-612. [CrossRef]

16. Mandalaki, M.; Papantoniou, S.; Tsoutsos, T. Assessment of energy production from photovoltaic modules integrated in typical shading devices. Sustain. Cities Soc. 2014, 10, 222-231. [CrossRef]

17. Kapsis, K.; Athienitis, A.K. A study of the potential benefits of semi-transparent photovoltaics in commercial buildings. Sol. Energy 2015, 115, 120-132. [CrossRef]

18. Ghosh, A.; Sarmah, N.; Sundaram, S.; Mallick, T.K. Numerical studies of thermal comfort for semi-transparent building integrated photovoltaic (BIPV)-vacuum glazing system. Sol. Energy 2019, 190, 608-616. [CrossRef]

19. Alrashidi, H.; Ghosh, A.; Issa, W.; Sellami, N.; Mallick, T.K.; Sundaram, S. Evaluation of solar factor using spectral analysis for CdTe photovoltaic glazing. Mater. Lett. 2019, 237, 332-335. [CrossRef]

20. Bhandari, S.; Roy, A.; Ghosh, A.; Mallick, T.K.; Sundaram, S. Perceiving the Temperature Coefficient of Carbon-based Perovskite Solar Cells. Sustain. Energy Fuels 2020, 4, 6283-6298. [CrossRef]

21. Ghosh, A.; Bhandari, S.; Sundaram, S.; Mallick, T.K. Carbon counter electrode mesoscopic ambient processed \& characterised perovskite for adaptive BIPV fenestration. Renew. Energy 2020, 145, 2151-2158.

22. Roy, A.; Ghosh, A.; Bhandari, S.; Selvaraj, P.; Sundaram, S.; Mallick, T.K. Color comfort evaluation of dye-sensitized solar cell (DSSC) based building-integrated photovoltaic (BIPV) glazing after 2 years of ambient exposure. J. Phys. Chem. C 2019, 123, 23834-23837. [CrossRef]

23. Selvaraj, P.; Ghosh, A.; Mallick, T.K.; Sundaram, S. Investigation of semi-transparent dye-sensitized solar cells for fenestration integration. Renew. Energy 2019, 141, 516-525. [CrossRef]

24. Myong, S.Y.; Jeon, S.W. Design of esthetic color for thin-film silicon semi-transparent photovoltaic modules. Sol. Energy Mater. Sol. Cells 2015, 143, 442-449. [CrossRef] 
25. Ghosh, A. Potential of building integrated and attached/applied photovoltaic (BIPV/BAPV) for adaptive less energy-hungry building's skin: A comprehensive Review. J. Clean. Prod. 2020, 276, 123343. [CrossRef]

26. Kirimtat, A.; Koyunbaba, B.K.; Chatzikonstantinou, I.; Sariyildiz, S. Review of simulation modeling for shading devices in buildings. Renew. Sustain. Energy Rev. 2016, 53, 23-49. [CrossRef]

27. Al-Masrani, S.M.; Al-Obaidi, K.M. Dynamic shading systems: A review of design parameters, platforms and evaluation strategies. Autom. Constr. 2019, 102, 195-216. [CrossRef]

28. Settino, J.; Carpino, C.; Perrella, S.; Arcuri, N. Multi-Objective Analysis of a Fixed Solar Shading System in Different Climatic Areas. Energies 2020, 13, 3249. [CrossRef]

29. Zhang, W.; Lu, L.; Peng, J. Evaluation of potential benefits of solar photovoltaic shadings in Hong Kong. Energy 2017, 137, 1152-1158. [CrossRef]

30. Yoo, S.-H.; Manz, H. Available remodeling simulation for a BIPV as a shading device. Sol. Energy Mater. Sol. Cells 2011, 95, 394-397. [CrossRef]

31. Jayathissa, P.; Luzzatto, M.; Schmidli, J.; Hofer, J.; Nagy, Z.; Schlueter, A. Optimising building net energy demand with dynamic BIPV shading. Appl. Energy 2017, 202, 726-735. [CrossRef]

32. Kim, J.J.; Jung, S.K.; Choi, Y.S.; Kim, J.T. Optimization of photovoltaic integrated shading devices. Indoor Built Environ. 2010, 19, 114-122. [CrossRef]

33. Jung, S.K.; Kim, Y.; Moon, J.W. Performance Evaluation of Control Methods for PV-Integrated Shading Devices. Energies 2020, 13, 3171. [CrossRef]

34. Bellia, L.; De Falco, F.; Minichiello, F. Effects of solar shading devices on energy requirements of standalone office buildings for Italian climates. Appl. Therm. Eng. 2013, 54, 190-201. [CrossRef]

35. Khoroshiltseva, M.; Slanzi, D.; Poli, I. A Pareto-based multi-objective optimization algorithm to design energy-efficient shading devices. Appl. Energy 2016, 184, 1400-1410. [CrossRef]

36. Ahmed, W.; Asif, M. BIM-based techno-economic assessment of energy retrofitting residential buildings in hot humid climate. Energy Build. 2020, 227, 110406. [CrossRef]

37. Alardhi, A.; Alaboodi, A.S.; Almasri, R. Impact of the new Saudi energy conservation code on Saudi Arabia residential buildings. Aust. J. Mech. Eng. 2020. [CrossRef]

38. Imam, A.A.; Al-Turki, Y.A. Techno-Economic Feasibility Assessment of Grid-Connected PV Systems for Residential Buildings in Saudi Arabia-A Case Study. Sustainability 2020, 12, 262. [CrossRef]

39. Lopez-Ruiz, H.G.; Blazquez, J.; Vittorio, M. Assessing residential solar rooftop potential in Saudi Arabia using nighttime satellite images: A study for the city of Riyadh. Energy Policy 2020, 140, 111399. [CrossRef]

40. Mesloub, A.; Ghosh, A. Daylighting Performance of Light Shelf Photovoltaics (LSPV) for Office Buildings in Hot Desert-Like Regions. Appl. Sci. 2020, 10, 7959. [CrossRef]

41. Oh, S.-C.; Hildreth, A.J. Energy Simulation Using EnergyPlus ${ }^{\mathrm{TM}}$ for Building and Process Energy Balance. In Analytics for Smart Energy Management; Springer: Berlin/Heidelberg, Germany, 2016; pp. 199-244.

42. Jakubiec, J.A.; Reinhart, C.F. DIVA: 2.0 Integrating daylight and thermal simulations using Rhinoceros 3D, Daysim and EnergyPlus. In Proceedings of the Building Simulation, Sydney, Australia, 14-16 November 2011.

43. Ruiz, G.R.; Bandera, C.F. Validation of calibrated energy models: Common errors. Energies 2017, 10, 1587. [CrossRef]

44. Kontes, G.D.; Giannakis, G.I.; Horn, P.; Steiger, S.; Rovas, D.V. Using thermostats for indoor climate control in office buildings: The effect on thermal comfort. Energies 2017, 10, 1368. [CrossRef]

45. Lee, K.S.; Han, K.J.; Lee, J.W. The impact of shading type and azimuth orientation on the daylighting in a classroom-focusing on effectiveness of façade shading, comparing the results of DA and UDI. Energies 2017, 10, 635. [CrossRef]

46. Mesloub, A.; Albaqawy, G.A.; Kandar, M.Z. The Optimum Performance of Building Integrated Photovoltaic (BIPV) Windows Under a Semi-Arid Climate in Algerian Office Buildings. Sustainability 2020, 12, 1654. [CrossRef]

Publisher's Note: MDPI stays neutral with regard to jurisdictional claims in published maps and institutional affiliations. 